УДК 616.61-089.87: 616.61-007.61:611.061.1

DOI: $10.24061 / 1727-0847.17 .3 .2018 .6$

\title{
В.М. Монастирський
}

Кафедра хірургії факультету післядипломної освіти (зав. - проф. А.І. Суходоля)

Вінницький національний медичний університет імені М.I. Пирогова

\section{ХАРАКТЕРИСТИКА ПАРАМЕТРІВ НИРКИ ЗА ДАНИМИ МАГНІТНО-РЕЗОНАНСНОЇ ТОМОГРАФІЇ ХВОРИХ НА СЕЧОКАМ'ЯНУ ХВОРОБУ В ОСІБ 3 ЄДИНОЮ НИРКОЮ}

Резюме. Проведено комплексне обстеження 84 хворих на сечокам’яну хворобу з єдиною ниркою та 65 хворих 3 двома нирками, які не мали захворювань нирок та сечових шляхів. Встановлено, що морфометричні параметри єдиної нирки (довжина, ширина, товщина та об'єм) хворих на сечокам'яну хворобу статистично значуще відрізнялися від аналогічних показників у пацієнтів, які не мали захворювань нирок та сечових шляхів. Показник об'єму правої єдиної нирки у чоловіків, хворих на СКХ, порівняно $з$ аналогічним показником у пацієнтів 3 двома нирками, які не мали захворювань нирок та сечових шляхів, був найбільшим: понад два рази $(\mathrm{p}<0,05)$.

Ключові слова: сечокам’яна хвороба; єдина нирка; розміри нирки; магнітно-резонансна томографія.

Сечокам'яна хвороба (СКХ) є одним 3 найпоширеніших захворювань нирок і сечовивідних шляхів [1]. Вона посідає друге місце у структурі патології нирок і сечових шляхів, третє місце у структурі причин смерті та четверте - у структурі інвалідності при урологічній патології. СКХ реєструється серед населення всіх країн світу з частотою 10-30 випадків на 1000 осіб дорослого населення і становить $30-40 \%$ від усіх урологічних захворювань [2]. Зокрема, поширеність уролітіазу в Німеччині становить 4,7\%, в Індії - 7,6\%, його захворюваність збільшилося в тричі за останні три десятиліття [3, 4]. В Україні захворюваність, за даними звернень, становить 778,9 на 100000 населення [5].

Окрім високої захворюваності, актуальність проблеми полягає і в тому, що хвороба має тривалий, часто рецидивуючий перебіг. Серед причин інвалідності внаслідок урологічних захворювань СКХ посідає третє місце слідом за злоякісними новоутвореннями і пієлонефритом, що пов'язано 3 прогресуючим порушенням анатомічного i функціонального стану нирок i сечовивідних шляхів, часто закінчується хронічною нирковою недостатністю [6].

Єдиної причини виникнення СКХ немає. Сприяють розвитку хвороби цілий ряд екзогенних факторів як кліматичні умови, особливості грунту та хімічного складу води, режим харчування, малорухливість, робота у гарячих цехах, так і ендогенні фактори, до яких можна віднести мета- болічні розлади, інфекційні захворювання сечових шляхів, спадкову схильність [7]. Підвищений вміст у сироватці крові кальцію у хворих на СКХ з єдиною, що залишилася, ниркою, а також високий рівень сечової кислоти дає привід зважати на постійне електролітне навантаження організму [8].

Недостатньо досліджені зміни місцевого масштабу, пов'язані з розміщенням сечових шляхів, розмірів єдиної нирки та топографоанатомічного положення нирки, що порушують відтік сечі, сприяють накопиченню та утворенню солей у мисці нирки.

Після виконання нефректомії в нирці, що залишилась, виникають структурні та функціональні зміни, найчастіше виникають пієлонефрит і нефролітіаз (79,3\%). Водночас спостерігається превалювання хворих з великими і коралоподібними каменями, що призводить до порушення функції єдиної нирки і хронічної ниркової недостатності [9]. Нефролітіаз нерідко виявляється вже через 1-4 роки після нефректомії, незалежно від причини, тобто в період функціональної реабілітації єдиної нирки [10]. Частота рецидиву нефролітіазу в осіб з однією ниркою досить висока: від 12,0 до 17,3\% раніше оперованих стосовно СКХ і 30,0-46,2\% хворих, оперованих 3 приводу множинних і коралоподібних каменів єдиної нирки [11].

Мета дослідження: порівняти розміри єдиної нирки у хворих на сечокам'яну хворобу з па- 
раметрами нирок хворих 3 двома нирками, які не мали захворювань нирок та сечових шляхів.

Матеріал і методи. Обстежено 149 хворих на базі Хмельницької обласної та міської лікарень. Хворих розподілили на основну та порівняльну групи. До основної групи залучали 84 хворих з єдиною ниркою з різним строком післяоперачійного періоду після видалення нирки, уяких діагностували СКХ. Серед них було 36 чоловіків та 48 жінок віком від 21 до 60 років, а середній вікстановив 42, 7£4,5 років. До порівняльної групи зарахували 65 хворих із двома нирками, які не мали захворювань нирок та сечових иляхів або інших хронічних захворювань, щуо могли б викликати ускладнення з боку органів сечової системи. Аналіз обстежених паџієнтів за віковою характеристикою показав, щуо пацієнти з двома нирками за віковими параметрами були репрезентативні хворим основної групи.

Усі хворі на СКХ основної групи з єдиною ниркою обстежувались через 2-5 років після видалення нирки, причому у 47 хворих видалена ліва нирка, а у 39-права. У пачієнтів причинами нефректомї були злоякісні новоутворення нирки, нирковокам'яна хвороба, гідронефроз, туберкульоз нирки, травми нирки, зморщена нирка, абсцес нирки та інші хвороби.

Основну групу формували суцільним методом, відібравщи усіх хворих на СКХ з єдиною ниркою, яким проводили амбулаторне чи стаціонарне лікування. Вибірку порівняльної групи сформували рандомізовано, відбираючи випадково хворих без ураження сечової системи, яким проводилосякомп'ютерно-томографічне дослідження поперекової ділянки. Обидві групи були схожими за основними порівнювальними параметрами.

Серед обстежених хворих на СКХ з єдиною ниркою у нашому дослідженні найбільше представлені хворі з післяопераційним періодом від двох до п'яти років (84 хворих). Це пояснюється тим, щзо порушень функиіі нирки у ией період найбільше. Спостерігається переважання кількості жінок у всіх термінах післяопераційного nepiody.

Характерно, щчо найчастіше $(49,1 \%)$ нирковокам'яна хвороба супроводжувалася пієлонефритом.

На час формування досліджуваних груп у хворих з єдиною ниркою виявили супутні захворювання, серед яких найбільш часто траплялись: остеохондроз, серчево-судинні хвороби, геморой, хронічний холецистит, дискінезї жовчного мі- хура та жовчних иляхів.

У хворих порівняльної групи діагностували неалкогольну жсрову хворобу печінки, хронічний панкреатит, пухлини шлунка, хвороби серцево-судинної системи.

Дослідження проводили на магнітно-резонансному-томографі Philips Intera-1,5T (стандартний протокол магнітного резонансу вмішував сканування в сагітальній, фронтальній та аксіальній проекціях з отриманням T1 зважених зображень). У Т2-зваженому зображенні контури нирки та ниркової пазухи були недостатньо чіткими.

У фронтальній проекиії магнітно-резонансної томограми (МРТ) на середньому зрізі нирки вимірювали довжсиу нирки, иирину верхнього полюса нирки, иирину нижнього полюса нирки, иирину нирки на рівні воріт нирки, довжину воріт нирки (рисунок).

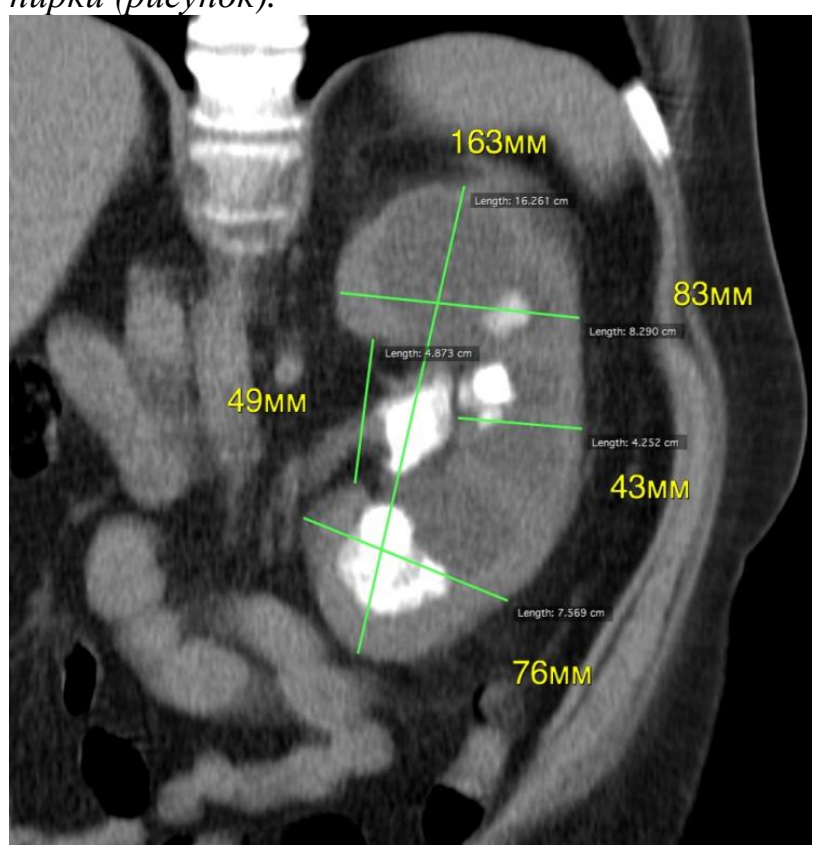

Рисунок. Морфометричні розміри лівої єдиної нирки хворого Д. (53 роки) на СКХ у фронтальній проекиії нирки: довжина нирки (163 мм), иирина верхнього полюса нирки (83 мм), иирина нижнього полюса нирки (76 мм), иирина нирки на рівні воріт (43 мм), довжина воріт нирки (49 мм)

Довжину нирки вимірювали між найбільш віддаленими точками верхнього і нижнього полюсів нирки, иирина верхнього полюса - відстань між найбільи віддаленими один від одного точками верхнього полюса, перпендикулярна довжнику нирки, иирина нижнього полюса відстань між найбільи віддаленими один від одного точками нижнього полюса, перпендикулярна довжнику нирки, иирина нирки на рівні воріт - 
відстань перпендикулярна довжнику нирки від середини воріт до бічного ії краю, довжина воріт нирки - найкоротша відстань між верхньою $i$ нижньою межами воріт нирки.

У сагітальній проекиії на середньому зрізі нирки вимірювали товщину верхнього полюса нирки, товщину нижнього полюса нирки та товщиину на рівні воріт нирки.

Товщиину верхнього полюса нирки вимірювали між найбільш найбільшою відстанню між передньою $і$ задньою поверхнею на рівні основи верхнього полюса. Товщина нижнього полюса найбільша відстань між передньою $i$ задньою поверхнею нирки на рівні основи нижнього полюса, а товщина на рівні воріт нирки - найбільша відстань між передньою $i$ задньою поверхнею нирки на рівні воріт нирки.

Визначення об'єму нирки здійснювали на основі математичної моделі еліпсоїда обертання, щчо дає найбільшу точність [12].

Об 'єм був розрахований як об'єм модифікованого еліпсоїда для кожної нирки, використовуючи формулу:

об' ${ }^{\prime} \mathcal{\prime}=\pi / 6 \times$ довжина $\times$ ширина $\times$ товщина

Довжина, иирина та товщина вимірювалися в міліметрах.

Статистична обробка отриманих результатів проведена з застосуванням програми "STATISTICA 5.5” фipми Statsoft, лічензійний № AXXR910A374605FA з використанням параметричних і непараметричних методів оцінки отриманих результатів.

Результати досліджень та їх обговорення. Вимірювання параметрів єдиної нирки (довжини, ширини, товщини та об'єму) хворих на СКХ показало значну відмінність від аналогічних показників у пацієнтів 3 двома нирками, які не мали захворювань нирок та сечових шляхів (табл. 1). Наприклад, у чоловіків, хворих на СКХ, довжина правої єдиної нирки статистично значуще більша (в 1,18 раза), ніж у чоловіків 3 двома нирками, які не мали захворювань нирок та сечових шляхів $(\mathrm{p}<0,05)$. Ширина, товщина та об'єм нирки теж були статистично значуще більшими відповідно в 1,25 раза, в 1,27 раза та 2,01 рази $(\mathrm{p}<0,05)$. У жінок 3 єдиною правою ниркою, хворих на СКХ, параметри нирки (довжина, ширина, товщина та об'єм) були більшими відповідно в 1,21 раза, 1,26 раза, 1,26 раза та 1,93 раза.

Морфометричні розміри лівої єдиної нирки (довжина, ширина, товщина та об'єм) у чоловіків, хворих на СКХ, теж були статистично значуще більшими відповідно в 1,15 раза, 1,23 раза, 1,21 раза, 1,71 раза $(\mathrm{p}<0,05)$ порівняно $з$ параметрами лівої нирки чоловіків 3 двома нирками, які не мали захворювань нирок та сечових шляхів (табл. 2). У жінок розміри нирки теж були більшими: довжина - в 1,30 раза, ширина - в 1,23 раза, товщина в 1,26 раза та об' $є$ м - в 1,86 раза.

Отже, проведені дослідження розмірів єдиної нирки у хворих на СКХ через 2-5 років після видалення нирки 3 допомогою магнітно-резонансної томографії виявили більші розміри нирки (ширини, довжини, товщини) та об'єму нирки, знання яких необхідне з урахуванням того, що єдина нирка $є$ фактором ризику раннього розвитку хронічної ниркової недостатності [13]. 3 допомогою математичного моделювання нами доведено, що

Таблиия 1

Розміри сдиної нирки у хворих на СКХ за даними МРТ

\begin{tabular}{|l|c|c|c|c|}
\hline \multirow{2}{*}{ Параметри нирки } & \multicolumn{2}{|c|}{ Права нирка } & \multicolumn{2}{c|}{ Ліва нирка } \\
\cline { 2 - 5 } & Чол. (n-15) & Жін. (n-20) & Чол. (n-21) & Жін. (n-28) \\
\hline Довжина (см) & $12,25 \pm 0,34^{*}$ & $11,66 \pm 0,15^{*}$ & $12,16 \pm 0,25^{*}$ & $12,83 \pm 0,22^{*}$ \\
\hline Ширина (см) & $6,80 \pm 0,24^{*}$ & $6,81 \pm 0,20^{*}$ & $6,74 \pm 0,24^{*}$ & $6,71 \pm 0,31^{*}$ \\
\hline Товщина (см) & $6,19 \pm 0,23^{*}$ & $6,20 \pm 0,22^{*}$ & $6,05 \pm 0,31^{*}$ & $6,29 \pm 0,34^{*}$ \\
\hline Об’єм (см $\left.{ }^{2}\right)$ & $261,43 \pm 11,22^{*}$ & $257,13 \pm 12,11^{*}$ & $258,47 \pm 13,12^{*}$ & $260,37 \pm 11,51^{*}$ \\
\hline
\end{tabular}

Примітка: * - статистично значущі відмінності $(p<0,05)$ за критерієм Мана-Уітні між відповідними показниками порівняно з показниками хворих, які не мали захворювань нирок та сечових шляхів

Розміри нирок пацієнтів, які не мали захворювань нирок та сечових шляхів, за даними МРТ (n-65)

\begin{tabular}{|l|c|c|c|c|}
\hline \multirow{2}{*}{ Параметри нирки } & \multicolumn{2}{|c|}{ Права нирка } & \multicolumn{2}{c|}{ Ліва нирка } \\
\cline { 2 - 5 } & Чол. & Жін. & Чол. & Жін. \\
\hline Довжина (см) & $10,42 \pm 0,32$ & $9,61 \pm 0,22$ & $10,56 \pm 0,28$ & $9,85 \pm 0,23$ \\
\hline Ширина (см) & $5,46 \pm 0,28$ & $5,40 \pm 0,21$ & $5,48 \pm 0,28$ & $5,46 \pm 0,23$ \\
\hline Товщина (см) & $4,89 \pm 0,23$ & $4,91 \pm 0,21$ & $5,01 \pm 0,23$ & $4,99 \pm 0,22$ \\
\hline${\left.\text { Об'єм (см }{ }^{2}\right)}^{144,92 \pm 9,12}$ & $133,35 \pm 8,91$ & $151,39 \pm 9,14$ & $140,23 \pm 8,66$ \\
\hline
\end{tabular}


при збільшенні об'єму нирки (маси нирки) за умови, коли ширина, довжина та товщина нирки збільшується пропорційно, тобто площина матеріальної симетрії $є$ незмінною, рух нирки відбувається за рахунок іiї повороту в площині матеріальної симетрії за годинниковою стрілкою [14].

Висновки. 1. Морфометричні параметри єдиної нирки у хворих на СКХ (довжина, ширина, товщина та об'єм) статистично значуще відрізнялися від аналогічних показників у пацієнтів 3 двома нирками, які не мали захворювань нирок та сечових шляхів. 2. Показник об'єму правої єдиної нирки у чоловіків, хворих на сечокам'яну хворобу порівняно з аналогічним показником у пацієнтів 3 двома нирками, які не мали захворювань нирок та сечових шляхів, був найбільшим ( $<<0,05)$.

Перспективи подальших досліджень. В подальшому перспективно дослідити зміни положення єдиної нирки у хворих на сечокам'яну хворобу.

\section{Список використаної літератури:}

1. Возіанов СО, Бойко АI, Спиридоненко ВВ, Мороз ОЛ, Гурженко АЮ, Купрін ДІ, Шматюк ТI, та ін. Оптимізація зменшення рещидивів пієлонефриту в осіб з уретеролітіазом єдиної нирки після контактної літотрипсії. Урологія. 2015;19(2):30-9.

2. Купрін ДІ, Бобрик МІ, Комісаренко ЮІ. Оиінка фільтрачійно-екскреторної функиї̈ єдиної нирки у пацієнтів із сечокам'яною хворобою на тлі иукрового діабету 2-го muny. International Journal of Endocrinology. 2018;14(4):334-8. DOI: http://dx.doi.org/10.22141/2224-0721.14.4.2018.140186

3. Fisang Ch, Anding R, Müller SC, Latz S, Laube N. Urolithiasis-an Interdisciplinary Diagnostic, Therapeutic and Secondary Preventive Challenge. Dtsch Arztebl Int. 2015 Feb;112(6): 83-91. Doi: 10.3238 / arztebl.2015.0083

4. Kumari A, Dokwal S, Mittal P, Kumar R, Goel R, Bansal P., Kumar HD, Bhutani J. An increase incidence in uric acid nephrolithiasis: changing patterns. J Clin Diagn Res. 2016;Jul;10(7):Bc01-Bc03. doi: [ 10.7860 /JCDR / 2016 / 19714.8139]

5. Дмитришин, СП. Сечокам'яна хвороба: епідеміологічні особливості в регіональному аспекті. Урологія. 2015;19(4):21-9.

6. Филиппович ВА. Мочекаменная болезнь. Пособие для студентов лечебного, медико-психологического и медико-диагностического факультетов. Гродно: ГрГМУ, 2015.41 с.

7. Saucier NA, Sinha MK, Liang KV, Krambeck AE, Weaver AL, Bergstralh EJ, Li X, et al. Risk factors for CKD in persons with kidney stones: a case-control study in Olmsted County, Minnesota. Am. J. Kidney Dis. 2010 okt;55(1):61-8. doi: [ 10.1053/j.ajkd.2009.08.008 ]

8. Абдихаликов ТЖ. Функциональное состояние единственной оставщейся почки у больных, в длительном катанамнезе перенесших операчию по поводу мочекаменной болезни. Вестник Кыргызско-российского славянского университета. 2016; 16(7):3-6.

9. Иванов АП, Тюзиков ИА. Нефрэктомия в современных условиях: причины и дальнейшая судьба больныхх с единственной почкой. Фундаментальные исследования. 2011;7:64-6.

10. Бойко АІ, Гурженко АЮ. Особливості перебігу нефролітіазу у паиієнтів з єдиною «здоровою» ниркою, яка залишилася після нефректомії з причини різних захворювань. Здоровье мужжины. 2013 (3,46):131-7.

11. Тюзиков ИА, Греков ЕА, Мартов АГ. Заболевания единственной почки: научная история и эволюиия проблемы. Урология. 2013 (6):103-110.

12. Новічіхін ОВ, Квятковська ТО. Магнітно-резонансна томографія і морфометрія нирок у людей різних вікових груп. Урологія. 2005 (1):16-20.

13. Аверьянова НИ, Мироненкова ЕГ, Ланских АВ, Еремеева ИВ. Возрастные особенности анатомии и показателей допплерограммы единственной почки (по данным ультразвукового исследования). Пермский медищинский журнал. 2006; 23(6):32-41.

14. Monastirskiy VM, Pivtorak VI, Fedotov VA. Modeling of possible movements of a single human kidney. Deutscher Wissenschaftsherold. 2017;5:31-3. doi://dwherold.de/onewebmedia/2017/5-2017/Monastyrskiy\%2031-33.pdf

\section{References}

1. Vozianov SO, Boyko AI, Spyrydonenko VV, Moroz OL, Hurzhenko AYu, Kuprin DI, et al. Optymizatsiya zmenshennya retsydyviv piyelonefrytu $v$ osib z ureterolitiazom yedynoyi nyrky pislya kontaktnoyi litotrypsiyi [Optimization of reduction of relapses of pyelonephritis in individuals with ureterolithiasis of a single kidney after contact lithotripsy]. Urolohiya. 2015;19(2):30-9. (in Ukrainian). 
2. Kuprin DI, Bobryk MI, Komisarenko YuI. Otsinka filtratsiino-ekskretornoi funktsii yedynoi nyrky u patsiientiv iz sechokamianoiu khvoroboiu na tli tsukrovoho diabetu 2-ho typu [Evaluating the excretory function of solitary kidney in patients with urolithiasis on a background of type 2 diabetes mellitus]. International Journal of Endocrinology. 2018;14(4):334-8. doi:10.22141/2224-0721.14.4.2018.140186 (in Ukrainian).

3. Fisang Ch, Anding R, Müller SC, Latz S, Laube N. Urolithiasis-an Interdisciplinary Diagnostic, Therapeutic and Secondary Preventive Challenge. Dtsch Arztebl Int. 2015 Feb;112(6):83-91. Doi: 10.3238 / arztebl.2015.0083

4. Kumari A, Dokwal S, Mittal P, Kumar R, Goel R, Bansal P, Kumar HD, Bhutani J. An increase incidence in uric acid nephrolithiasis: changing patterns. J Clin Diagn Res. 2016;Jul;10(7):Bc01-Bc03. doi: [ 10.7860 / JCDR / 2016 / 19714.8139]

5. Dmytryshyn SP. Sechokamiana khvoroba: epidemiolohichni osoblyvosti v rehionalnomu aspekti [Urolithiasis: epidemiology features in a regional aspect]. Urologiya. 2015;19(4):21-9. (in Ukrainian)

6. Filippovich VA. Mochekamennaya bolezn. Posobie dlya studentov lechebnogo, mediko-psihologicheskogo $i$ mediko-diagnosticheskogo fakultetov [Urolithiasis disease. A manual for students of medical, medical-psychological and medical-diagnostic faculties]. Grodno: GrGMU; 2015. 41 p. (in Russian).

7. Saucier NA, Sinha MK, Liang KV, Krambeck AE, Weaver AL, Bergstralh EJ, Li X, et al. Risk factors for CKD in persons with kidney stones: a case-control study in Olmsted County, Minnesota. Am. J. Kidney Dis. 2010;55(1):61-8. doi: [ 10.1053/j.ajkd.2009.08.008]

8. Abdihalikov TZh. Funktsionalnoe sostoyanie edinstvennoy ostavsheysya pochki u bolnyih, $v$ ditelnom katanamneze perenesshih operatsiyu po povodu mochekamennoy bolezni [Functional condition of the single kidney in patients after surgical intervention due to urinary stone disease]. Vestnik Kyirgyizsko-rossiyskogo slavyanskogo universiteta. 2016;16(7):3-6. (in Russian).

9. Ivanov AP, Tjuzikov IA. Nefrjektomija v sovremennyh uslovijah: prichiny i dal'nejshaja sud'ba bol'nyh $s$ edinstvennoj pochkoj [Nephrectomy in modern conditions: the reasons and further destiny of the patients with a solitary kidney]. Fundamental'nye issledovanija. 2011;(7):64-6. (in Russian).

10. Boyko AI, Hurzhenko AYu. Osoblyvosti perebihu nefrolitiazu u patsiyentiv z yedynoyu "zdorovoyu» nyrkoyu, yaka zalyshylasya pislya nefrektomiyi z prychyny riznykh zakhvoryuvan' [The peculiarities of the course of nephrolithiasis in patients with solitary kidney that remained after nephrectomy due to various diseases]. Zdorov'e muzhchyn. 2013;(3):131-7. (in Ukrainian).

11. Tyuzikov IA, Grekov EA, Martov AG. Zabolevaniya edinstvennoy pochki: nauchnaya istoriya i evolyutsiya problemyi [Single kidney diseases: scientific history and evolution of the problem]. Urologiya. 2013;(6):10310.

12. Novichikhin OV, Kviatkovska TO. Mahnitno-rezonansna tomohrafiia i morfometriia nyrok u liudei riznykh vikovykh hrup. [Magnetic resonance imaging and morphometry of the kidneys in people of different age groups]. Urolohiia. 2005;(1):16-20. (in Ukrainian).

13. Averyanova NI, Mironenkova EG, Lanskih AV, Eremeeva IV. Vozrastnyie osobennosti anatomii i pokazateley dopplerogrammyi edinstvennoy pochki (po dannyim ultrazvukovogo issledovaniya) [Age peculiar features of anatomy and dopplerogram indices of a single kidney (by ultrasound investigation data)]. Permskiy meditsinskiy zhurnal. 2006;23(6):32-41. (in Russian).

14. Monastirskiy VM, Pivtorak VI, Fedotov VA. Modeling of possible movements of a single human kidney. Deutscher wissenschaftsherold. German Science Herald. 2017 Sept;(5):31-3.

\section{ХАРАКТЕРИСТИКА ПАРАМЕТРОВ ПОЧКИ ПО ДАННЫМ МАГНИТНО-РЕЗОНАНСНОЙ ТОМОГРАФИИ БОЛЬНЫХ МОЧЕКАМЕННОЙ БОЛЕЗНЬЮ У ЛИЦ С ЕДИНСТВЕННОЙ ПОЧКОЙ}

Резюме. Проведено комплексное обследование 84 больных мочекаменной болезнью с единственной почкой и 65 больных с двумя почками, которые не имели заболеваний почек и мочевых путей. Установлено, что морфометрические параметры единственной почки (длина, ширина, толщина и объем) больных МКБ статистически значимое отличались от аналогичных показателей у пациентов, не имевших заболеваний почек и мочевых путей. Показатель объема правой единственной почки у мужчин, больных МКБ, по сравнению с аналогичным показателем у пациентов с двумя почками, которые не имели заболеваний почек и мочевых путей, был наибольшим: больше чем в 2 раза $(\mathrm{p}<0,05)$.

Ключевые слова: мочекаменная болезнь; единственная почка; размеры почки; магнитно-резонансная томография. 
CHARACTERISTICS OF THE KIDNEY PARAMETERS ACCORDING TO THE DATA OF MAGNETIC RESONANCE IMAGING OF PATIENTS WITH UROLITHIASIS IN PERSONS WITH A SINGLE KIDNEY

Abstract. Urolithiasis is one of the most common diseases of the kidneys and urinary tract. The purpose of the study is to compare the size of a single kidney in patients with urolithiasis with parameters of the kidneys of patients with two kidneys who don't have any diseases of the kidneys and urinary tract. A comprehensive examination of 84 patients with urolithiasis and single kidney and 65 patients with two kidneys who didn't have any kidney and urinary tract diseases were conducted. The research was carried out on a magnetic resonance tomography Philips Intera-1,5T (standard magnetic resonance protocol included scanning in sagittal, frontal and axial projections to obtain T1 images). The length of the right single kidney is statistically significantly greater (1.18 times) in men with urolithiasis than in men with two kidneys who did not have any kidney and urinary tract disorders $(\mathrm{p}<0.05)$. The width, thickness and volume of the kidneys were also statistically significantly larger respectively 1.25 times, 1.27 times and 2.01 times $(\mathrm{p}<0.05)$. The parameters of the kidney (length, width, thickness and volume) were larger, respectively, in 1.21 times, 1.26 times, 1.26 times and 1.93 times in women with the single right kidney with urolithiasis. Conclusion. The morphometric parameters of a single kidney in patients with urolithiasis (length, width, thickness and volume) were statistically significantly different from those in patients with two kidneys who don't have any kidney and urinary tract disorders. The measure of the volume of the right single kidney in men suffering from urolithiasis was the highest $(\mathrm{p}<0.05)$ in comparison with the same parameters in patients with two kidneys who don't have any kidney and urinary tract disorders.

Key words: urolithiasis; single kidney; kidney size; magnetic resonance imaging.

\section{Відомості про автора:}

Монастирський В.М. - канд. мед. наук, доцент каф. хірургії факультету післядипломної освіти, Вінницький національний медичний університет імені М.I. Пирогова.

Information about author:

Monastirskiy Volodymyr M. - MD, PhD, Associate Professor Department Surgery Faculty of Postgraduate Education, National M.I. Pirogov Memorial Medical University.

Надійшла 12.06 .2018 p. Рецензент - проф. Зайцев В.І. (Чернівці) 